\title{
Behavior of Acetyl Groups Combined with Sulfhydryl Groups in Protein
}

\author{
I. Acetylation of Sulfhydryl Groups in Yeast Alcohol Dehydrogenase
}

\author{
Kihachiro Uehara, Junji Umemoto, ${ }^{1}$ Morio Yonezawa ${ }^{2}$ \\ AND SHUJI OHKUBo ${ }^{3,4}$
}

Laboratory of Biochemistry, Faculty of Pharmaceutical

Sciences, Osaka University, Toyonaka, Osaka (Post No. 560)

\author{
(Received May 4, 1971)
}

\begin{abstract}
It was found that highly purified crystalline yeast alcohol dehydrogenase (YADH) was still contaminated with a small amount of thiolesterase. Separation of these two enzymes from each other was performed by DEAE-cellulose column chromatography. YADH preparation resulted from this treatment was found to be homogeneous by disc electrophoresis and chromatography on hydroxylapatite column.

Treatment of pure YADH with 0 , S-diacetylthiamine (DAT) in $0.05 \mathrm{M}$ phosphate buffer at $\mathrm{pH} 6.0$ and $30^{\circ}$ resulted in $50 \%$ inactivation of the enzyme with concomitant loss of two SH groups per mole of the protein. Reaction of the DAT-inactivated YADH with hydroxylamine resulted in full reactivation accompanied by restoration of $\mathrm{SH}$ groups to the level of the native enzyme.

These results supply evidence that the change in enzymatic activity that occurs upon treatment of YADH with DAT is the consequence of acetylation of two SH groups essential for activity per molecule of the enzyme.
\end{abstract}

Although a considerable information about the chemical feature of acetyl groups combined with $\mathrm{SH}^{*}$ groups of substances of low molecular weight, such as $\mathrm{CoA}$ and GSH, has been obtained, relatively little attention has been given to that of acetyl groups combined with $\mathrm{SH}$ groups in protein.

The present studies have been undertaken to reveal the chemical properties of acetyl groups combined with protein $\mathrm{SH}$ groups, and also to verify our hypothesis that in living cells, $\mathrm{SH}$ groups in some protein are acetylated to form $S$-acetyl-protein, and the proteinbound acetyl groups are transferred to $\mathrm{SH}$ group of CoA to yield acetyl-CoA and oxidized further in Krebs tricarboxylic acid cycle.

This paper describes a method for acetylation of $\mathrm{SH}$ groups in $\mathrm{YADH}(\mathrm{EC}$ 1.1.1.1)

\footnotetext{
1 Present address : Department of Pharmacy, Faculty of Science and Engineering, Nihon University

2 Present address : Radiation Center of Osaka Prefecture, Division of Medicine and Hygiene

${ }^{3}$ Present address : Kyowa Hakko Company

4 上原喜八郎, 梅本準治, 米沢司郎, 大久保修司

* The abbreviations used are: SH, sulfhydryl; CoA, coenzyme A; GSH, glutathione; YADH, yeast alcohol dehydrogenase; DAT, $O, S$-diacetylthiamine; OAT, $O$-acetylthiamine; NAD, nicotinamide-adenine dinucleotide; $\mathrm{NADH}$, reduced form of nicotinamide-adenine dinucleotide; acetyl-SG, acetyl glutathione; PCMB, p-chloromercuribenzoate.
} 
together with changes that occur in the enzymatic activity upon acetylation. YADH contains essential $\mathrm{SH}$ groups for activity and constitutes a convenient test object for acetylation of protein, because the modification of $\mathrm{SH}$ groups in $\mathrm{YADH}$ can be observed not only by chemical method but also by means of changes in the catalytic activity.

DAT is used as a reagent for acetylation of protein in the present experiments, since this reagent is considered to react with protein $\mathrm{SH}$ groups as shown in Scheme 1. Treatment of YADH with DAT under an appropriate condition results in acetylation of two $\mathrm{SH}$ groups in the enzyme molecule accompanied by decrease in the catalytic activity. $S$-Acetyl$\mathrm{YADH}$ resulted from the acetylation has been isolated, which shows $50 \%$ of activity of the native enzyme.
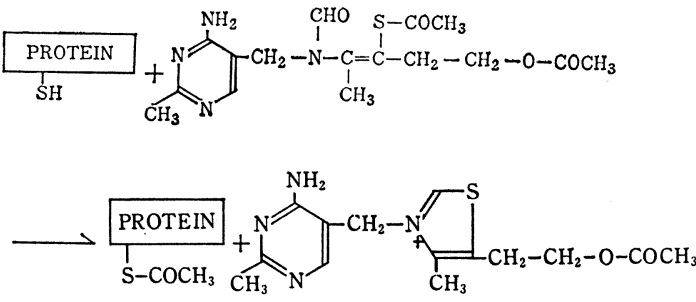

SCHEME 1 Reaction of DAT with protein $S H$ group

\section{EXPERIMENTAL}

\section{Materials}

DAT and OAT were prepared from thiamine hydrochloride according to the method of Matsukawa et al. (1) and determined by cyanogen bromide reaction of Matsui (2). NAD and $\mathrm{NADH}$ were obtained from Sigma and determined by the method of Ciotti et al. (3). Acetyl-SG was synthesized by the method of Kielly et al. (4). Hydroxylapatite was prepared according to the method of Tiselius et al. (5). DEAE-cellulose was a product of Serva, and baker's yeast was purchased from Oriental Yeast.

2. Preparation of Pure YADH and Assay of the Enzyme

$\mathrm{YADH}$ was prepared by the method described by Ohta et al. (6) with slight modifi- cations as follows. In the first fractionation of crude yeast extract with ammonium sulfate, solid ammonium sulfate was added to the extract until a final saturation of 0.65 was reached and kept overnight at $4^{\circ}$. Then the resulting precipitate was collected.

In the step of crystallization of YADH from the solution obtained by negative adsorption on DEAE-cellulose column, the solution was brought to 0.65 saturation with ammonium sulfate. The precipitate was collected and dissolved in a minimal volume of $0.01 \mathrm{M}$ phosphate buffer, $\mathrm{pH}$ 7.5. To this solution was added slowly saturated ammonium sulfate solution, previously adjusted to $\mathrm{pH} 7.5$ with $1 \mathrm{~N}$ ammonia solution. Crystals obtained by 0.35 saturation of ammonium sulfate were collected. Recrystallization was performed according to the method of Hayes et al. (7) and the resulting crystals were further purified by DEAEcellulose column chromatography as described in the following section. The purified preparation (specific activity $110,000-140,000$ ) was provided for the experiments.

Enzyme assay was carried out by the method of Racker (8) and the activity was represented by Racker units. The enzyme solution was diluted, if necessary, with $0.05 \mathrm{M}$ phosphate buffer, $\mathrm{pH}$ 6.0, for assay.

Protein was estimated by measuring absorbance at $280 \mathrm{~m} \mu$. Molecular weight for the enzyme of 150,000 (7) and the molecular extinction coefficient at $280 \mathrm{~m} \mu$ of $1.89 \times 10^{5} \mathrm{~cm}^{2}$ mole $^{-1}(7)$ were used in the calculation.

\section{DEAE-cellulose Column Chromatogra-} phy

Crystalline YADH was dissolved in $1.0 \mathrm{ml}$ of $0.013 \mathrm{M}$ phosphate buffer, $\mathrm{pH} 7.2$, and applied to a column of Sephadex G-25 $(1 \times 25$ $\mathrm{cm})$ to remove ammonium sulfate. A $10 \mathrm{ml}$ solution of the above fraction $(54.6 \mathrm{mg}$ of protein) was applied to a column of DEAEcellulose $(2.1 \times 27 \mathrm{~cm})$ equilibrated with the above buffer. The column was washed with the same buffer and then eluted with $0.03 \mathrm{M}$ phosphate buffer at a flow rate of $10 \mathrm{ml}$ per hour. Fractions of $5.3 \mathrm{ml}$ were collected. These operations were performed at $4^{\circ}$. 


\section{Hydroxylapatite Column Chromatogra- phy}

The enzyme was dissolved in $0.01 \mathrm{M}$ phosphate buffer, $\mathrm{pH} 7.2$, and $7.5 \mathrm{ml}$ of the solution (2.5 mg of protein) was applied to a column of hydroxylapatite $(1.6 \times 16 \mathrm{~cm})$ equilibrated with $0.01 \mathrm{~m}$ phosphate buffer, $\mathrm{pH} 7.2$, in $0.2 \mathrm{M}$ sodium chloride. Elution was performed with an exponential gradient generated with a closed mixing chamber containing $150 \mathrm{ml}$ of $0.013 \mathrm{M}$ phosphate buffer, $\mathrm{pH} 7.2$, in $0.2 \mathrm{M}$ sodium chloride and a reservoir containing $290 \mathrm{ml}$ of $0.164 \mathrm{~m}$ phosphate buffer, $\mathrm{pH} 7.2$, in $0.2 \mathrm{M}$ sodium 'chloride at a flow rate of $20 \mathrm{ml}$ per hour.

\section{Determination of SH Groups in YADH}

Titration of $\mathrm{SH}$ groups in $\mathrm{YADH}$ with PCMB was carried out essentially according to the method of Boyer (9). Approximately 0.1 $\mathrm{mM}$ solution of $\mathrm{PCMB}$ was added by portionwise to the known amount of YADH solution below $15^{\circ}$. Titration was followed by the increase in absorbance at $250 \mathrm{~m} \mu$. Number of $\mathrm{SH}$ groups was determined from the end point of the titration.

\section{Detection of Thiolesterase Activity}

Activity of crude thiolesterase obtained from beef liver was determined as follows with the use of acetyl-SG as a substrate (10). To $0.95 \mathrm{ml}$ of $0.2 \mathrm{~mm}$ acetyl-SG solution was added $0.05 \mathrm{ml}$ of enzyme solution. After the mixture was incubated at $30^{\circ}$ for 30 minutes, $2.0 \mathrm{ml}$ of $0.025 \mathrm{~mm}$ PCMB solution was added. Number of $\mathrm{SH}$ groups was determined by the method of Boyer (9).

\section{Disc Electrophoresis of Purified YADH}

Electrophoresis on polyacrylamide gels at pH 8.0 was performed as described by Williams et al. (11). To $0.02 \mathrm{ml}-0.07 \mathrm{ml}$ of YADH solution (20-30 $\mu \mathrm{g}$ of protein) was added 0.15 $\mathrm{ml}$ of $50 \%$ sucrose solution, and the mixture was layered onto the gel. Electrophoresis was continued for 90 minutes at $220 \mathrm{~V}, 3.2 \mathrm{~mA}$ per column and $15^{\circ}$.

\section{Acetylation of $Y A D H$ with DAT}

Unless otherwise stated, acetylation was carried out at $\mathrm{pH} 6.0$ and $30^{\circ}$ by incubating $1.0 \mathrm{ml}$ of $33 \mu \mathrm{M}$ YADH solution in $0.05 \mathrm{M}$ phosphate buffer, $\mathrm{pH} 6.0$, with $1.0 \mathrm{ml}$ of 136.4 mM DAT solution in the same buffer for 30 minutes. The protein was separated from reagent by passage through a Sephadex G-25 column $(1.0 \times 20 \mathrm{~cm})$ in the cold. Aliquots of the protein effluent were taken up for determination of $\mathrm{YADH}$ activity and contents of $\mathrm{SH}$ groups. The recovery of the protein, as measured by ultraviolet absorption, was about $94 \%$. The acetylated YADH could be stored by lyophilization of the effluent to dryness immediately after the gel filtration.

\section{Detection of Acetohydroxamate}

The lyophilized, reagent free protein sample, which lost $50 \%$ of its original YADH activity as a result of reaction of the enzyme with DAT, was dissolved in $0.05 \mathrm{M}$ phosphate buffer, $\mathrm{pH}$ 7.0. To $12 \mathrm{ml}$ (60 $\mathrm{mg}$ of protein) of this solution was added $12 \mathrm{ml}$ of $0.2 \mathrm{~m}$ hydroxylamine solution dissolved in the same buffer. After incubation at $30^{\circ}$ for 10 minutes, the reaction mixture was applied to a column of Sephadex G-25 $(2 \times 60 \mathrm{~cm})$ and eluted with water. Region corresponding to the fractions which contained acetohydroxamate was calibrated with authentic compound prior to the application of the sample. Those fractions were collected and applied to a column of Dowex $50 \times 4 \mathrm{w}\left(\mathrm{H}^{+}\right.$form $)(1 \times 17 \mathrm{~cm})$. The effluent was adjusted to $\mathrm{pH} 5.0$ with ammonia and concentrated under reduced pressure at $35^{\circ}$. The residue was examined by thin layer chromatography on cellulose powder with $n$-butanol -acetic acid-water $(4: 1: 5)$ as the solvent. The spot was located by spraying with ferric chloride reagent $(0.37 \mathrm{M}$ ferric chloride solution containing $0.2 \mathrm{M}$ trichloroacetic acid and $0.66 \mathrm{M}$ hydrochloric acid), and compared with authentic acetohydroxamate $\left(R_{F} \quad 0.69\right)$, which was synthesized from acetic anhydride and hydroxylamine (12).

\section{Results}

\section{Purification of Crystalline $Y A D H$}

A specific enzyme which catalyzes release of acetyl groups combined with protein $\mathrm{SH}$ groups to form acetic acid has not yet been reported. However, it seems reasonable to 


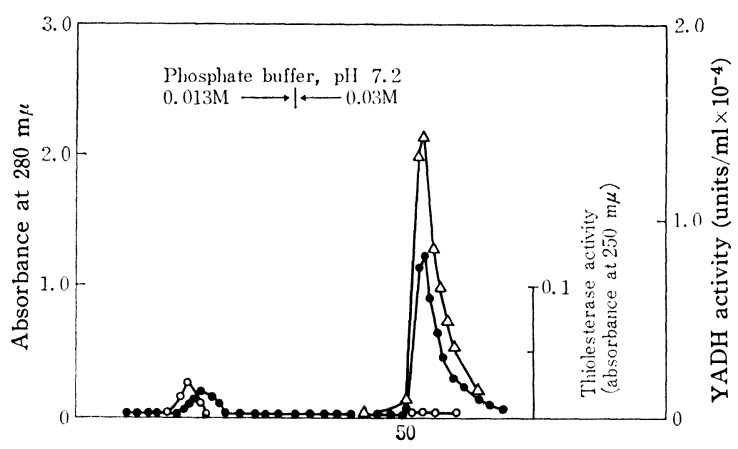

Tube number $(5.3 \mathrm{ml} / \mathrm{tube})$

FIG. 1 DEAE-cellulose column chromatography of crystalline $Y A D H$

Crystalline YADH solution (54.6 mg of protein) was applied to a column of DEAE-cellulose $(2.1 \times 27$ $\mathrm{cm}$ ) equilibrated with $0.013 \mathrm{M}$ phosphate buffer, $\mathrm{pH}$ 7.2. Elution was performed with the indicated buffer at a flow rate of $10 \mathrm{ml}$ per hour at $4^{\circ}$. Fractions of $5.3 \mathrm{ml}$ were collected.

- - Absorbance at $280 \mathrm{~m} \mu$; - $\mathrm{O}-$, Thiolesterase activity; $-\triangle-$, YADH activity.

assume that, if $\mathrm{YADH}$ preparation contains thiolesterase activity, then hydrolysis of thiolester bonds in $\mathrm{YADH}$, which are expected to be produced by acetylation of the enzyme, takes place. Therefore a problem, first of all, whether crystalline YADH contains thiolesterase or not should be resolved. Search for thiolesterase activity in $\mathrm{YADH}$ preparation and disc electrophoresis of the preparation have revealed that crystalline $\mathrm{YADH}$, prepared by the procedure as described in preceding section, is still contaminated with a small amount of thiolesterase and it is not homogeneous as shown in Fig. 2 (a). Further purification of crystalline YADH was performed by DEAE-cellulose column chromatography. A typical elution pattern is shown in Fig. 1.

The first peak contained all of thiolesterase and no YADH, while the second peak contained all of YADH and no thiolesterase. $\mathrm{YADH}$ thus obtained appeared to be homogeneous on disc elec$Y A D H$

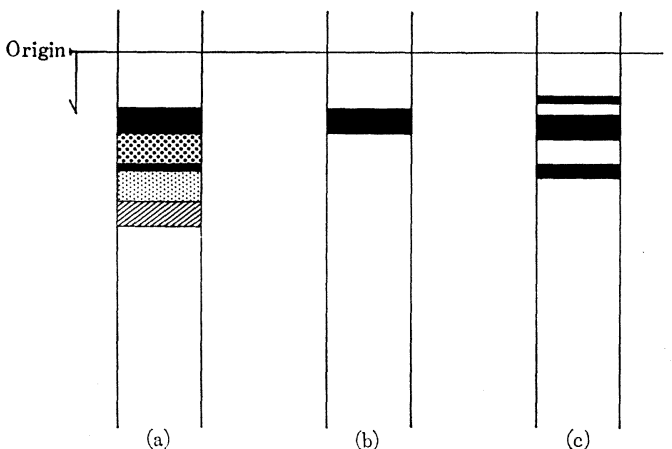

FIG. 2 Polyacrylamide gel disc electrophoretic patterns of YADH preparations.

Electrophoresis on polyacrylamide gel was performed at $\mathrm{pH} 8.0$ and $3.2 \mathrm{~mA}$ per column for 90 minutes at $15^{\circ}$.

(a), Crystalline $\mathrm{YADH}$; (b), YADH fraction obtained from DEAE-cellulose column chromatography of (a); (c), After crystallization of (b).

trophoresis (Fig. 2 (b)). Purity of YADH eluting in the second peak was also estimated by hydroxylapatite column chromatography. As shown in Fig. 3, enzymatically active area was found to correspond exactly to the protein region. The recovery of $\mathrm{YADH}$ from the chromatogram, as judged by ultraviolet absorption, was theoretical.

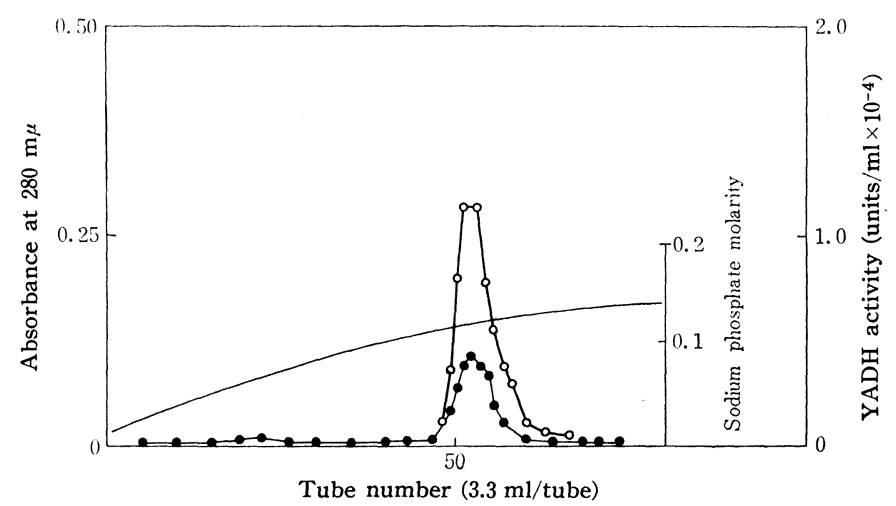

FIG. 3 Hydroxylapatite column chromatography of purified

The enzyme solution ( $2.5 \mathrm{mg}$ of protein) was applied to a column of hydroxylapatite $(1.6 \times 16 \mathrm{~cm})$ equilibrated with $0.01 \mathrm{M}$ phosphate buffer, $\mathrm{pH} 7.2$, in $0.2 \mathrm{M}$ sodium chloride. Elution was performed with an exponential gradient generated with a closed mixing chamber containing $150 \mathrm{ml}$ of $0.013 \mathrm{M}$ phosphate buffer, $\mathrm{pH} 7.2$, in $0.2 \mathrm{M}$ sodium chloride and a reservoir containing $290 \mathrm{ml}$ of $0.164 \mathrm{M}$ phosphate buffer, $\mathrm{pH} 7.2$, in $0.2 \mathrm{M}$ sodium chloride at a flow rate of $20 \mathrm{ml}$ per hour.

- - Absorbance at $280 \mathrm{~m} \mu$; - O-, YADH activity. 
These results indicate that the most pure YADH free from thiolesterase can be prepared from crystalline YADH by DEAE-cellulose column chromatography. The pure YADH preparation obtained by this procedure was used throughout the further studies.

After aging for 24 hours at $4^{\circ}$ or crystallization of this preparation, it was observed that two distinct protein components appeared on disc electrophoresis. Fig. 2 shows the gel electrophoretic patterns of $\mathrm{YADH}$ preparations before (b) and after (c) crystallization. Appearance of those new components is probably attributed to partial denaturation of $\mathrm{YADH}$.

\section{Acetylation of $Y A D H$ with $D A T$}

\section{1) Effect of DAT on YADH}

When YADH was treated with DAT as described in preceding section, experimental 8 , the activity of YADH was rapidly reduced. About $50 \%$ loss of its original activity was attained within 30 minutes of incubation. In the absence of DAT, or in the presence of OAT or thiamine in place of DAT, no detectable change in enzymatic activity was observed during the incubation. In order to reveal the mechanism of inactivation of YADH with DAT, interactions between DAT and various amino acids or GSH were investigated. Amounts of OAT produced by the reaction were quantitatively determined to follow the reaction, because formation of OAT was expected to result from transfer of acetyl groups, if possible, from DAT to those compounds.

To $0.5 \mathrm{ml}$ of solution of amino acids or GSH in $0.05 \mathrm{M}$ phosphate buffer, $\mathrm{pH} 6.0$, was added $0.5 \mathrm{ml}$ of $82 \mathrm{~mm}$ DAT solution in the same buffer, and incubated at $30^{\circ}$. Final concentration of GSH and amino acids except tyrosine was $1.25 \mathrm{~mm}$ and that of tyrosine was $0.156 \mathrm{~mm}$. The results presented in Fig. 4 indicate that cysteine, GSH and histidine react with DAT to form OAT but other amino acids are inert under this condition.

In the case of reaction of cysteine with DAT, two moles of OAT were formed per mole of cysteine, since the acetylation led to the formation of $N, S$-diacetyl-cysteine (13). In the reaction of histidine with DAT, formation

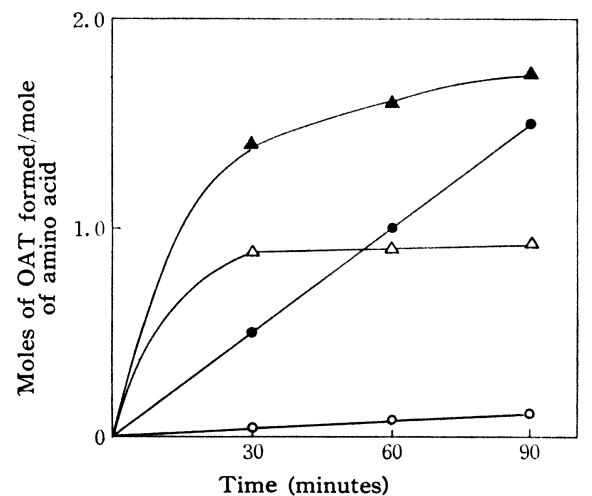

FIG. 4 Reaction of DAT with various amino acids or $G S H$

To $0.5 \mathrm{ml}$ of solution of amino acids or GSH in $0.05 \mathrm{M}$ phosphate buffer, $\mathrm{pH} 6.0$, was added $0.5 \mathrm{ml}$ of $82 \mathrm{mM}$ DAT solution in the same buffer, and incubated at $30^{\circ}$. Final concentration of GSH and amino acids except tyrosine was $1.25 \mathrm{mM}$ and that of tyrosine was $0.156 \mathrm{mM}$.

$-\Delta-$, Cysteine ; $-\triangle-$, GSH ; - - , Histidine; - O-, Serine, lysine, alanine, arginine, tyrosine, glutamic acid, methionine, or DAT alone.

of OAT proceed linearly with time due to catalytic action of histidine itself that hydrolyzes easily thiolester bond in DAT to give OAT and acetic acid (14).

Whitehead et al. have reported that upon carboxymethylation of $\mathrm{SH}$ groups in $\mathrm{YADH}$ with monoiodoacetamide the enzyme is inactivated, and protection against this inactivation can be observed in the presence of $1.67 \mathrm{~mm}$ NAD or NADH (15).

Reaction of YADH with DAT was carried out by incubating $0.1 \mathrm{ml}$ of $\mathrm{YADH}$ solution $(0.8 \mathrm{mg}$ of protein) in $0.05 \mathrm{M}$ phosphate buffer, $\mathrm{pH} 6.0$, with $0.4 \mathrm{ml}$ of $0.171 \mathrm{M}$ DAT solution in the same buffer and an additional $0.5 \mathrm{ml}$ of the same buffer in a total volume of $1.0 \mathrm{ml}$ at $30^{\circ}$. After incubating for 40 minutes, about $50 \%$ of its original activity was lost. While in the presence of $0.5 \mathrm{ml}$ of $3.34 \mathrm{~mm} \mathrm{NAD}$ or $\mathrm{NADH}$ solution in the same buffer in place of $0.5 \mathrm{ml}$ of the buffer solution, the activity was reduced only $20 \%$ by the reaction with DAT. It was apparent that the effective protection was afforded by the coenzyme. From these results, it was suggested that the inactivation of $\mathrm{YADH}$ by the reaction with DAT was 


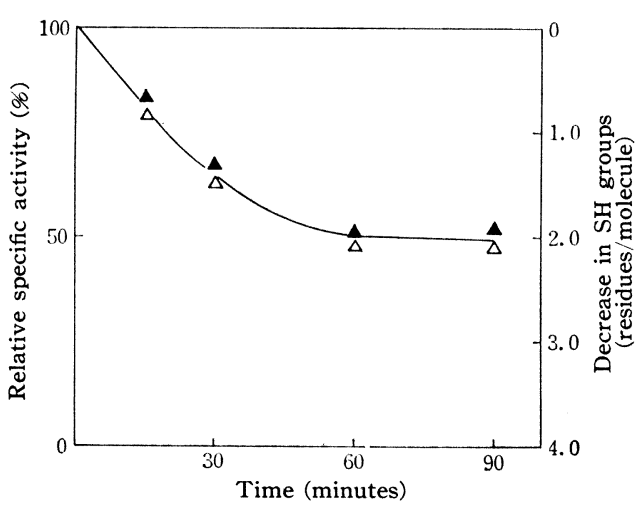

FIG. 5 Effect of DAT on YADH

Reacton of $\mathrm{YADH}$ with DAT was carried out by incubating $1.0 \mathrm{ml}$ of $33 \mu \mathrm{M}$ YADH solution in $0.05 \mathrm{M}$ phosphate buffer, $\mathrm{pH} 6.0$, with $1.0 \mathrm{ml}$ of 136.4 mM DAT solution in the same buffer at $30^{\circ}$. The protein was separated from reagent by passage through a Sephadex G-25 column $(1.0 \times 20 \mathrm{~cm})$ in the cold. Aliquots of the protein effluent were taken up for determination of YADH activity and contents of $\mathrm{SH}$ groups.

$-\triangle-, \mathrm{YADH}$ activity; $-\boldsymbol{\Delta}-\mathrm{SH}$ contents.

probably attributed to acetylation of $\mathrm{SH}$ groups in the enzyme. Fig. 5 summarizes the results of a number of experiments designed to relate the loss of free $\mathrm{SH}$ groups during the reaction and the changes in enzymatic activity. The data show parallel losses in $\mathrm{SH}$ groups and catalytic activity of the enzyme.

It was evident that $50 \%$ loss in enzymatic activity was associated with the loss of two $\mathrm{SH}$ groups per mole of YADH. Upon further incubation after 60 minute incubation period, no further decrease in $\mathrm{SH}$ groups was observed. Formation of OAT was linearly related to the incubation time and it was quantitatively independent of the decrease in SH groups.

2) Reactivation of DAT-inactivated YADH

The decrease in enzymatic activity of YADH appears to be a consequence of acetylation of $\mathrm{SH}$ groups in the enzyme. If so, it seems possible to assume that DAT-inactivated $\mathrm{YADH}$ is readily reactivated by release of acetyl groups bound to protein $\mathrm{SH}$ groups under a mild condition.

In general, it is known that among acetyl groups combined with amino, hydroxyl or $\mathrm{SH}$ groups, only acetyl group bound to $\mathrm{SH}$ group
TABLE 1

Restoration of enzymatic activity and SH contents of DAT-treated YADH by hydroxylamine

\begin{tabular}{lccc}
\hline \multicolumn{1}{c}{ Sample } & $\begin{array}{c}\text { Incubation } \\
\text { time }\end{array}$ & $\begin{array}{c}\text { Remaining } \\
\text { activity }\end{array}$ & $\begin{array}{l}\text { Decrease in } \\
\text { SH groups }\end{array}$ \\
\hline & minutes & $\begin{array}{c}\text { units/mg, } \\
(\%)\end{array}$ & $\begin{array}{c}\text { residues/ } \\
\text { molecule }\end{array}$ \\
YADH & - & $15.0 \times 10^{4}(100)$ & - \\
DAT-treated YADH & 0 & $7.7 \times 10^{4}(52)$ & $1.6-2.0$ \\
DAT-treated YADH & 7 & $9.6 \times 10^{4}(64)$ & $1.2-1.7$ \\
DAT-treated YADH & 7 & $14.2 \times 10^{4}(96)$ & $0-0.2$ \\
$+\mathrm{NH}_{2} \mathrm{OH}$ & & & \\
\hline
\end{tabular}

To $1.6 \mathrm{ml}$ of DAT-treated YADH solution in $0.05 \mathrm{M}$ phosphate buffer, $\mathrm{pH} 6.0,(1.424 \mathrm{mg}$ of protein) was added $0.4 \mathrm{ml}$ of $0.5 \mathrm{M}$ hydroxylamine solution, and incubated for 7 minutes at $30^{\circ}$. The mixture was then passed through a Sephadex G-25 column, and $\mathrm{YADH}$ activity and $\mathrm{SH}$ contents of the protein fraction were determined.

can be released upon treatment with hydroxylamine in a low concentration at a neutral $\mathrm{pH}$ to form acetohydroxamate.

A sample of DAT-treated YADH, in which the activity was reduced to $50 \%$ of the initial activity with concomitant loss of two $\mathrm{SH}$ groups per mole of the enzyme, was incubated with $0.1 \mathrm{M}$ hydroxylamine in $0.05 \mathrm{M}$ phosphate buffer, $\mathrm{pH} 6.0$, at $30^{\circ}$ for 7 minutes, and the mixture was passed through a Sephadex G-25 column. $\mathrm{YADH}$ activity and $\mathrm{SH}$ contents of the protein fraction were determined. As shown in Table 1 , treatment of the DAT-inactivated $\mathrm{YADH}$ with hydroxylamine resulted in a rapid, full reactivation accompanied by restoration of $\mathrm{SH}$ groups to the level of the native enzyme.

Furthermore, formation of acetohydroxamate was apparently observed by thin layer chromatography after incubation of $60 \mathrm{mg}$ of DAT-treated YADH (50\% loss in initial activity) with hydroxylamine under the condition as described above.

The restoration of activity by hydroxylamine, together with the formation of acetohydroxamate give strong evidence that the change in catalytic activity that arises from reaction of DAT with YADH is a consequence of acetylation of $\mathrm{SH}$ groups in $\mathrm{YADH}$.

There was a possibility that formation of disulfide bond might occur oxidatively between thiol type of OAT and $\mathrm{SH}$ groups in $\mathrm{YADH}$. 
However, the possibility was ruled out completely because such disulfide bond formation, as measured by the method of Utsumi et al. (16), could not be observed upon incubation of YADH with DAT at $\mathrm{pH} 6.0,7.0$ and 8.0.

Under the experimental conditions mentioned above, only two $\mathrm{SH}$ groups in $\mathrm{YADH}$ were acetylated by DAT. In a further effort to acetylate more than two $\mathrm{SH}$ groups in YADH molecule, the reaction was carried out with about four-fold higher concentration of DAT. In this case, the activity of $\mathrm{YADH}$ was reduced to $30 \%$ of its original activity, whereas the decrease of $\mathrm{SH}$ contents of the enzyme was retained only two groups per mole of the protein. Restoration of YADH inactivated with high concentration of DAT was attempted by incubating it with hydroxylamine under the same experimental condition mentioned above. The loss in $\mathrm{SH}$ groups associated with the reaction of YADH with high concentration of DAT was found to be fully restorable, whereas loss in catalytic activity was regained to the level of $70 \%$ of the initial activity and found to be partially restorable.

At $\mathrm{pH} 6.0$, no more than two $\mathrm{SH}$ groups in $\mathrm{YADH}$ were acetylated even in the reaction with high concentration of DAT. Upon treatment of $\mathrm{YADH}$ with DAT at $\mathrm{pH} 7.0$ under the standard condition outlined in experimental section except $\mathrm{pH}$, extent of inactivation was increased, and treatment at $\mathrm{pH} 8.0$ resulted in complete inactivation of the enzyme, which was accompanied by the loss of $4.5 \mathrm{SH}$ groups per mole of YADH.

Table 1 also shows spontaneous restoration of catalytic activity and $\mathrm{SH}$ contents in DATinactivated $\mathrm{YADH}$ upon incubation at $30^{\circ}$. In the case where the enzyme was modified with high concentration of DAT, such spontaneous restoration could not be observed.

\section{Discussion}

It was found unexpectedly that YADH recrystallized several times still contained thiolesterase. Resolution of structures of these two enzymes in future will lead to an elucidation of this phenomenon.
Reaction of DAT with YADH at $\mathrm{pH} 6.0$ resulted in acetylation of two $\mathrm{SH}$ groups per mole of $\mathrm{YADH}$, and $50 \%$ of its original activity was concomitantly lost. The extent of inactivation of $\mathrm{YADH}$ increased as the $\mathrm{pH}$ of the reaction mixture was raised from neutral to alkaline regions. Complete loss in enzymatic activity was observed in the reaction at $\mathrm{pH}$ 8.0, in which $4.5 \mathrm{SH}$ groups per mole of the enzyme were lost. In the reaction of $\mathrm{YADH}$ with DAT in alkaline $\mathrm{pH}$ regions, it seems probable that irreversible inactivation of the enzyme takes place as a consequence of reactions of various groups in addition to acetylation of $\mathrm{SH}$ groups in the protein molecule.

\section{REFERENCES}

1. Matsukawa, T., and Kawasaki, H., Yakugaku Zasshi, 73, 705 (1953).

2. Matsui, K., Vitamins, 6, 148 (1955).

3. Ciotti, M. M., and Kaplan, N. O., in S.P. Colowick and N.O. Kaplan (Editors), Methods in Enzymology, Academic Press, New York, Vol. III, p.890 (1957).

4. Kielly, W.W., and Brady, L.B., J. Biol. Chem., 206, 327 (1954).

5. Tiselius, A., Hjerten, S., and Levin, O., Arch. Biochem. Biophys., 65, 132 (1956).

6. Ohta, T., and Ogura, Y., J. Biochem., 58, 73 (1965).

7. Hayes, J.E. Jr., and Velick, S.F., J. Biol. Chem., 207, 225 (1954).

8. Racker, E., in S.P. Colowick and N.O. Kaplan (Editors), Methods in Enzymology, Academic Press, New York, Vol. I, p. 500 (1955).

9. Boyer, P.D., J. Am. Chem. Soc., 76, 4331 (1954).

10. Uehara, K., and Kobashi, K., Seikagaku, 34, 19 (1962).

11. Williams, D.E., and Reisfeld, R.A., Ann. New York Acad. Sci., 121, Art. 2, 373 (1964).

12. Miolati, A., Ber. deut. chem. Ges., 25, 699 (1892).

13. Wieland, T., and Bokelmann, E., Ann., 576, 20 (1952).

14. Uehara, K., Murase, J., and Tsukamoto, M., Seikagáku, 34, 348 (1962).

15. Whitehead, E.P., and Rabin, B.R., Biochem. J., 90, 532 (1964).

16. Utsumi, I., Harada, K., Kohno, K., and Hirao, H., Vitamins, 26, 134 (1962). 